\title{
DUCKWEED: A MODEL FOR PHYTOREMEDIATION TECHNOLOGY
}

\author{
Leela Kaur*, Nupur Kanwar* \\ * Maharaja Ganga Singh University, Department of Environment Sciences, Bikaner, Rajasthan, India \\ corresponding author: Leela Kaur, e-mail: leela.kaur@gmail.com
}

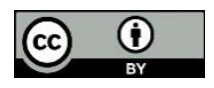

This work is licensed under a

Creative Commons Attribution 4.0

$\underline{\text { International License }}$
Review paper

Received: August $5^{\text {th }}$, 2020

Accepted: November $6^{\text {th }}, 2020$

HAE-1995

https://doi.org/10.33765/thate.12.1.4

\begin{abstract}
The Lemnaceae or duckweed family comprises 37 species of smallest and simplest flowering plants. Duckweeds have a fast growth rate, can survive under a wide range of temperature and $\mathrm{pH}$ conditions and are easy to maintain and harvest which makes them an excellent candidate for bioremediation of wastewaters. The main objective of the present review is to extend an appreciation for the potential of living and non-living biomass of duckweed in remediating waters contaminated with heavy metals. Along with showing the detailed mechanism of phytoremediation by duckweed, the paper also discusses the enhancement of duckweed phytoremediation by the integration of transgenic technology. Furthermore, the paper explores other applications of duckweed specifically as fuel, animal feed, in human nutrition, in medicine and as a life support system. Apart from this, various disposal mechanisms for harvested duckweed have been analysed. Current understanding of removal efficiencies of several contaminants by employing duckweed is limited mainly to laboratory experiments. More concentrated and persistent efforts to develop efficient approaches for the genetic transformation of duckweeds can expand the development and utilization of duckweeds.
\end{abstract}

Keywords: duckweed, phytoremediation, heavy metals, transgenic plants, non-living biomass

\section{INTRODUCTION}

At the present time, contamination of soil, surface water and groundwater with organic and inorganic pollutants and their restitution has become a paramount concern for environmentalists. Among such pollutants, increasing concentrations of heavy metals and their prolonged persistence in soil and water have created an alarming situation for human life and aquatic biota. Several physical and chemical techniques, inclusive of chemical precipitation, oxidation or reduction, filtration, ion exchange, reverse osmosis, membrane technology, evaporation and electrochemical treatment have been employed as remediation strategies. These techniques suffer from various limitations, namely high costs, low efficiency, generation of secondary pollutants, etc. and are not eco-friendly $[1,2]$. Hence it is a requisite to employ low cost and eco-friendly means of remediating media contaminated with heavy metals. Phytoremediation or use of plants as a tool for bioremediation of soil and 
water by extracting, sequestering or detoxifying contaminants has emerged as a more suitable alternative [3, 4]. This environmental clean-up technology, initially proposed by Utsumamiya (1980) and Chaney (1983) [5], is solar-driven and in average 10fold cheaper than engineering based heavy metal remediation methods, like ion exchange, filtration and absorption. Ideally, plants with fast growth rate, high biomass, easily harvestable, having a wide root system and that can tolerate and accumulate different types of heavy metals are considered suitable for phytoremediation $[6,7]$. The technology has five subsets applicable to toxic metal remediation from soil and water. These are:

- Phytoextraction - plant biomass induces contaminants into shoots after they are taken by the plant roots [8],

- Rhizofilteration - remediation of contaminated water by plant roots through absorption, concentration and precipitation [9],

- Phytostabilization - mobility of contaminants reduced by plant adsorption or precipitation [10],

- Phytovolatalization - uptake of pollutants and releasing them into the atmosphere after conversion into a volatile form [10].

Around 400 species of plants are hyperaccumulators that can absorb high concentrations of metal contaminants through their roots and are being used in phytoremediation. These plants have been found to accumulate metals at a rate 50 - 100 times higher than normal plants [11].

Aquatic plants play an important role in the uptake, storage and recycling of metals from wastewaters [12]. Aquatic plants like Eichhornia crassipes, Azolla filiculoides, Pistia stratiotes, Hydrilla verticillata, Typha domingensis, Salvinia cucullata, A. caroliniana, A. pinnata, Lemna minor, $L$. aequinoctialis, $L$. gibba and Spirodela polyrhiza are suitable for removal of heavy metals, as reported by several researchers [13 19]. Duckweed (known as a monocotyledon of the Lemnaceae family, recently classified as subfamily Lemnoideae among aroid family
Araceae [20]) is widely and efficiently used for phytoremediation of contaminated water due to its ability to grow in a wide range of temperature, $\mathrm{pH}$ and nutrient levels [21]. It is a small group of free-floating aquatic plants with only five genera: Spirodela, Landoltia, Lemna, Wolffia and Wolffiella and 37 species [22 24]. Different duckweed species exhibit variable sensitivity to heavy metals.

This paper provides a review on phytoremediation potential of duckweed for heavy metals, like chromium $(\mathrm{Cr})$, nickel $(\mathrm{Ni})$, lead $(\mathrm{Pb})$, zinc $(\mathrm{Zn})$, cadmium $(\mathrm{Cd})$, copper $(\mathrm{Cu})$, etc. along with a detailed mechanism of their removal from wastewaters. Furthermore, the paper discusses the approach of genetic engineering to enhance the duckweed phytoremediation ability. Besides, the paper explores other fields of duckweed application and alternatives for its disposal.

\section{DUCKWEED SPECIES PHYTOREMEDIATION}

Duckweeds are the smallest and simplest flowering plants that currently exist. They represent a highly modified structural organization, including the simplification and loss of many anatomical features [25]. Their reduced body structure is organized as "thalloid" or "frond" and stem is absent. Roots are simple in Lemna and are entirely lacking in two genera (Wolffia and Wolffiella). Though duckweeds are angiosperms, they dominantly reproduce by vegetative propagation. The utility of duckweed species for bioremediation is sustainable because they recycle the nutrient from the wastewater and recover the aquatic ecosystem efficiently [26]. An overview of studies regarding phytoremediation potential of different species of duckweed is presented hereinafter.

\section{Lemna}

Lemna minor (common duckweed) is commonly found in temperate regions, except Eastern Asia and Australia. Singh et al. [27] in 
his study has revealed that the duckweed $(L$. minor) showed better lead removal than other aquatic plants, such as Pistia stratiotes (Water Lettuce), E. crassipes (Water Hyacinth), Hydrila verticillata (Hydrilla) from polluted water and can be used in phytoremedial approaches. L. minor is not suitable for accumulation of $\mathrm{Ni}^{2+}$ from contaminated wastewaters [28]. L. minor can grow well in $\mathrm{pH}$ range 6 - 9 making it a suitable plant for phytoremediation. However, nitrate has few inhibitory effects on the plant growth [29]. Uysal [30] and Thayaparan et al. [31] showed that L. minor could efficiently reduce chromium in water at low concentration. Uysal and Taner [32] reported that lead accumulation in L. minor was highest at $\mathrm{pH} 4.5$ and then it decreased at $\mathrm{pH} 6$ which was later confirmed by Kaur et al. [33]. L. minor also showed great potential for the removal of chromium, zinc, lead and cadmium from textile wastewaters [34]. A comparative study conducted on $L$. minor and $E$. crassipes distinctly stated that $L$. minor can remove nickel metal more thoroughly as compared to E. crassipes [35]. L. gibba was found to be an appropriate remedy for boron at low concentrations (2 $\mathrm{mg} / \mathrm{l})$ [36]. It can also accumulate uranium $(120 \%)$, boron $(40 \%)$, and arsenic (133\%) [37]. Jafari and Akhavan [38] investigated the capacity of 3 duckweeds, L. minuta, L. minor, L. trisulca, to purify zinc polluted water, during which L. trisulca (97\%) was found to have highest percentage of removal. In another study, L. polyrhiza / Spirodela polyrhiza when exposed to $10 \mathrm{mg} / \mathrm{l}$ of zinc, lead and nickel for 4 days accumulated $27.0 \mu \mathrm{g} / \mathrm{mg}$ of zinc, 10.0 $\mu \mathrm{g} / \mathrm{mg}$ of lead and $5.5 \mu \mathrm{g} / \mathrm{mg}$ of nickel [39]. Azeez and Sabbar [40] in their study on phytoremediation of oil refinery by $L$. minor showed that it can successfully be used for wastewater pollutants removal. Daud et al. [41] in their study proved that L. minor significantly reduced the concentration of heavy metals in a landfill leachate. Removal efficiency of $L$. minor for all the metals from landfill leachate was more than $70 \%$, with the maximum value for copper $(91 \%)$. Studies have shown that L. minor has the potential to grow, develop and bioremediate iron rich mine effluent [42]. Both L. minor and Spirodela polyrhiza are potential cadmium accumulators [43].

\section{Spirodela}

Spirodela polyrhiza was found to be an extractor and accumulator of arsenic, nickel and cadmium [44, 45]. S. polyrhiza was seen to have accumulated more than $1000 \mathrm{mg} / \mathrm{kg}$ of lead and nickel in its dry biomass [46]. Islam et al. [47], while evaluating the performance of S. polyrhiza for treatment of $\mathrm{Cr}(\mathrm{VI})$ water, submitted that the high bioconcentration factor (4558) proved the appropriateness of the plant for extracting chromium metal from water. Spirodela exhibited symptoms of toxicity for zinc at high exposure concentrations (40 - 50 ppm) [48]. S. polyrhiza has been capable of removing cadmium and lead from media efficiently under laboratory conditions [49]. Loveson et al. [50] apprised that constructed wetlands with Spirodela mat may help prevent the spread of heavy metal contamination from land to the aquatic environment. High metal removal rates, close to $100 \%$, were reported in wetlands in the study, which is quite promising.

\section{Landoltia}

It consists of one species, namely Landoltia punctata. Its major application is in the field of starch production. Shi et al. [51] in their study compared the toxic effects of copper oxide nanoparticles ( $\mathrm{CuO}-\mathrm{NP})$ and soluble copper salt $\left(\mathrm{CuCl}_{2}\right)$ on L. punctata. The results stated that copper was easily absorbed from $\mathrm{CuO}-\mathrm{NP}$ suspension. Therefore, copper content was four times higher in $\mathrm{CuO}-\mathrm{NP}$ exposed fronds than in fronds exposed to equivalent dose of soluble copper.

\section{Wolffia}

Wolffia globosa is one of the smallest flowering plants consisting of small rootless spherical fronds. Zhang et al. [52] investigated potential of $W$. globosa for arsenic accumulation and found that it was able to 
accumulate $\geq 1000 \mathrm{mg} \mathrm{As} / \mathrm{kg}$ in frond dry weight (DW) and tolerate up to $400 \mathrm{mg} \mathrm{As} / \mathrm{kg}$ DW. Arsenite efflux appears to be the limiting factor in phytofilteration of arsenic using $W$. globosa. Moreover, W. globosa have shown a high level of tolerance to both chromium and cadmium [53]. Among five species of Wolffia (W. globosa, W. australiana, W. cylindracea, W. columbiana $W$. arrhiza). W. columbiana accumulated highest concentration of cadmium [54].

\section{Wolffiella}

Wolffiella is a genus of small rootless duckweed of the Lemnaceae family. No secondary research data was available on phytoremediation capacity of Wolffiella.

A summary of removal efficiencies of duckweed species for different heavy metals is presented in Table 1.

Table 1. Removal efficiency of duckweed for different heavy metals

\begin{tabular}{|c|c|c|c|c|c|c|c|}
\hline S. N. & Species used & Heavy metal & $\begin{array}{l}\text { Concentration } \\
\text { in medium }\end{array}$ & $\begin{array}{l}\text { Removal } \\
\text { efficiency } \\
(\%)\end{array}$ & $\begin{array}{c}\text { Accumulated } \\
\text { concentration in } \\
\text { plant }\end{array}$ & Remarks & Reference \\
\hline 1. & L. minor & Chromium & $5 \mathrm{mg} / \mathrm{L}$ & & $4.423 \mathrm{mg} \mathrm{Cr} / \mathrm{g}$ & $\mathrm{pH} 4.0$ & [30] \\
\hline 2. & L. minor & Zinc & $1-20 \mathrm{mg} / \mathrm{L}$ & $40-83$ & & & {$[38]$} \\
\hline 3. & L. minuta & Zinc & $1-20 \mathrm{mg} / \mathrm{L}$ & $35-89$ & & & [38] \\
\hline 4. & L. trisulca & Zinc & $1-20 \mathrm{mg} / \mathrm{L}$ & $49-97$ & & & {$[38]$} \\
\hline 5. & L. minor & Lead & $10 \mathrm{mg} / \mathrm{L}$ & 99.99 & & pH $5.0-6.0$ & [33] \\
\hline 6. & L. minor & Nickel & $10 \mathrm{mg} / \mathrm{L}$ & 99.30 & & $\mathrm{pH} 6.0$ & [33] \\
\hline 7. & L. minor & Lead & $16 \mu \mathrm{g} / \mathrm{L}$ & 98.70 & & \multirow{4}{*}{$\begin{array}{l}\text { Water sample - wastewater } \\
\text { from Basra Oil Refinery, } \\
\text { Iraq. }\end{array}$} & [40] \\
\hline 8. & L. minor & Copper & $12 \mu \mathrm{g} / \mathrm{L}$ & 99.80 & & & [40] \\
\hline 9. & L. minor & Zinc & $43 \mu \mathrm{g} / \mathrm{L}$ & 72.00 & & & {$[40]$} \\
\hline 10. & L. minor & Cadmium & $5.1 \mu \mathrm{g} / \mathrm{L}$ & 99.60 & & & [40] \\
\hline 11. & L. minor & Zinc & $1.47 \mathrm{mg} / \mathrm{L}$ & 83.00 & & \multirow{5}{*}{$\begin{array}{l}\text { Water sample - Mahmood } \\
\text { Booti landfill site, Iraq. }\end{array}$} & [41] \\
\hline 12. & L. minor & Lead & $0.83 \mathrm{mg} / \mathrm{L}$ & 78.00 & & & [41] \\
\hline 13. & L. minor & Iron & $1.17 \mathrm{mg} / \mathrm{L}$ & 77.00 & & & [41] \\
\hline 14. & L. minor & Copper & $0.69 \mathrm{mg} / \mathrm{L}$ & 91.00 & & & [41] \\
\hline 15. & L. minor & Nickel & $1.21 \mathrm{mg} / \mathrm{L}$ & 76.00 & & & [41] \\
\hline 16. & L. minor & Cadmium & $2 \mathrm{mg} / \mathrm{L}$ & & $4734.56 \mathrm{mg} / \mathrm{kg}$ & & [43] \\
\hline 17. & S. polyrhiza & Cadmium & $3 \mathrm{mg} / \mathrm{L}$ & & $7711.00 \mathrm{mg} / \mathrm{kg}$ & & [43] \\
\hline 18. & S. polyrhiza & Lead & $0.91 \mathrm{mg} / \mathrm{L}$ & 93.19 & & & [46] \\
\hline 19. & S. polyrhiza & Nickel & $2.92 \mathrm{mg} / \mathrm{L}$ & $70-80$ & & & [46] \\
\hline 20. & S. polyrhiza & Chromium & $4.5 \mathrm{mg} / \mathrm{L}$ & & $855.56 \mathrm{mg} / \mathrm{kg}$ & & [47] \\
\hline 21. & S. polyrhiza & Lead & $1 \mathrm{mg} / \mathrm{L}$ & 53 & & & [49] \\
\hline 22. & S. polyrhiza & Cadmium & $1 \mathrm{mg} / \mathrm{L}$ & 53 & & & [49] \\
\hline 23. & S. polyrhiza & Copper & $65 \mu \mathrm{g} / \mathrm{L}$ & 79 & & \multirow{8}{*}{$\begin{array}{c}\text { Water sample - a wetland } \\
\text { near Kuzhikundam Thodu } \\
\text { creek at a location near HIL } \\
\text { site boundary, Eloor } \\
\text { industrial area, Ernakulam, } \\
\text { Kerala, India. }\end{array}$} & [50] \\
\hline 24. & S polyrhiza & Lead & $26 \mu \mathrm{g} / \mathrm{L}$ & 95 & & & [50] \\
\hline 25. & S. polyrhiza & Zinc & $212 \mu \mathrm{g} / \mathrm{L}$ & 66 & & & [50] \\
\hline 26. & S. polyrhiza & Chromium & $118 \mu \mathrm{g} / 1$ & 53 & & & [50] \\
\hline 27. & S. polyrhiza & Cobalt & $7.2 \mu \mathrm{g} / \mathrm{L}$ & 28 & & & [50] \\
\hline 28. & S. polyrhiza & Manganese & $8 \mu \mathrm{g} / \mathrm{L}$ & 20 & & & [50] \\
\hline 29. & S. polyrhiza & Mercury & $23 \mu \mathrm{g} / \mathrm{L}$ & 45 & & & {$[50]$} \\
\hline 30. & S. polyrhiza & Nickel & $19.3 \mu \mathrm{g} / \mathrm{L}$ & 9 & & & [50] \\
\hline 31. & S. polyrhiza & Copper & $63 \mu \mathrm{g} / \mathrm{L}$ & 74 & & \multirow{10}{*}{$\begin{array}{l}\text { Water sample - wetlands } \\
\text { southwest of the } \\
\text { "Amanthuruthu" wetland } \\
\text { area, approx. } 150 \mathrm{~m} \text { west of } \\
\text { the HIL, Eloor industrial } \\
\text { area, Ernakulam, Kerala. }\end{array}$} & {$[50]$} \\
\hline 32. & S. polyrhiza & Lead & $34.4 \mu \mathrm{g} / \mathrm{L}$ & 91 & & & {$[50]$} \\
\hline 33. & S. polyrhiza & Zinc & $301 \mu \mathrm{g} / \mathrm{L}$ & 62.4 & & & [50] \\
\hline 34. & S. polyrhiza & Chromium & $121 \mu \mathrm{g} / \mathrm{L}$ & 49.0 & & & [50] \\
\hline 35. & S. polyrhiza & Cobalt & $8 \mu \mathrm{g} / \mathrm{L}$ & 40 & & & [50] \\
\hline 36. & S. polyrhiza & Manganese & $7.3 \mu \mathrm{g} / \mathrm{L}$ & 30.1 & & & [50] \\
\hline 37. & S. polyrhiza & Mercury & $3.4 \mu \mathrm{g} / \mathrm{L}$ & 53.0 & & & [50] \\
\hline 38. & S. polyrhiza & Nickel & $22.3 \mu \mathrm{g} / \mathrm{L}$ & 22.0 & & & [50] \\
\hline 39. & S. polyrhiza & Iron & $5.3 \mu \mathrm{g} / \mathrm{L}$ & 98.1 & & & [50] \\
\hline 40. & S. polyrhiza & Cadmium & $3 \mu \mathrm{g} / \mathrm{L}$ & 100 & & & [50] \\
\hline 41. & L. punctata & $\mathrm{Cu}$ salt $\left(\mathrm{CuCl}_{2}\right)$ & $0.6 \mathrm{mg} / \mathrm{L}$ & & $\begin{array}{c}\text { Roots: } 550- \\
600 \mu \mathrm{g} / \mathrm{g} \text { DW; } \\
\text { Fronds: } 400- \\
450 \mu \mathrm{g} / \mathrm{g} \text { DW }\end{array}$ & & [51] \\
\hline 42. & L. punctata & CuO-NP & $1.0 \mathrm{mg} / \mathrm{L}$ & & $\begin{array}{l}\text { Roots: } 800 \mu \mathrm{g} / \mathrm{g} \\
\text { DW aprox.; } \\
\text { Fronds: } 650- \\
700 \mu \mathrm{g} / \mathrm{g} \text { DW }\end{array}$ & & [51] \\
\hline 43. & W. globosa & Cadmium & $5 \mu \mathrm{M}$ & & $\begin{array}{c}143.12 \mathrm{mg} / \mathrm{kg} \\
\mathrm{FW}\end{array}$ & $\mathrm{pH} 6.0$ & [54] \\
\hline
\end{tabular}




\section{TYPES OF PHYTOREMEDIATION IN DUCKWEED}

After careful analysis of previous studies [17, $44,54,55$ - 57] it can be established that phytofiltration/rhizofiltration is the dominant mechanism of phytoremediation in duckweed. The phytoremediation potential of the duckweeds can be further enhanced by the application of innovative approaches in phytoremediation.

\section{Transgenic phytoremediation}

Duckweeds genome sizes vary enormously, ranging from 158 megabase pairs (Mbp) in Spirodela to $1881 \mathrm{Mbp}$ in Wolffia, a total 13fold change [58 - 61], indicating duckweeds as an interesting model for studying genome size evolution. Knowledge of molecular taxonomy has led to significant progress for exploitation of duckweed in toxic metal and metalloid phytoremediation. Li and Xiong [62] and Vunsh et al. [63] used polyploidization as a tool for genetic modification of duckweeds. Many attempts have been made to develop a technology of genetic engineering of exogenous genes into nuclear genome through agrobacterium-mediated transformation and regeneration from tissue culture $[64,65]$. This technology not only allows expressing recombinant protein, polymer, small molecules in duckweed system [66, 67], but facilitates functional gene studies in duckweeds as well [67]. The first stable transformed duckweed was obtained by Frey et al., (1980) through incubating intact plant of Lemna perpusilla with the Escherichia coli plasmids pMB9 and plasmid Bolivar Rodriguez 325 (pBR325) under optimized conditions [68]. Efficient genetic transformation protocols were developed in $L$. gibba and L. minor with a binary vector containing beta-glucuronidase and Neomycin phosphotransferase II (nptII) expression cassettes [67]. Transgenic duckweed could be regenerated after three months of agrobacterium-mediated transformation. The addition of the poorly assimilated carbohydrates of galactose or sorbitol yielded high levels of callus [64]. The stable and transgenic $S$. oligorrhiza showed a high protein yield, that is the transgene protein of Green fluorescent protein (GFP) expression, reached more than $25 \%$ of total soluble proteins [65]. Canto-Pastor et al. [69] engineered an artificial microRNA (amiRNA) gene silencing system in $L$. gibba. An Arabidopsis photorespiratory pathway gene serine glyoxylate aminotransferase (SGAT), named as AtAGT1, was successfully overexpressed in L. minor [70]. The gene expression response to cadmium stress in $L$. punctata 6001 was analysed via RNA-Seq technique by $\mathrm{Xu}$ et al. [71]. A summary of this and other stress responses of duckweed is available in Table 2. The transcriptomic study using RNA Seq to determine toxicity and tolerance of ammonium $\left(\mathrm{NH}_{4}{ }^{+}\right)$was reported in L. minor. Bioinformatical analysis identified 70,728 unigenes and 14,207 differentially expressed genes (DEGs), most of which were down-regulated under $\mathrm{NH}_{4}{ }^{+}$toxicity [72]. The gene expression data for ionizing radiation (IR) indicated that $L$. minor plants can shift from acclimation responses toward survival responses at increasing dose rates of ionising radiation [73]. Wang et al. [74] discovered that 3 days of exposure to $10 \mu \mathrm{M}$ abscisic acid $(\mathrm{ABA})$ induced irreversible turion development in Spirodela. Similar to a desiccating seed of a terrestrial plant, developing turions upregulated five and expressed two previously silent genes of the Late Embryogenesis Abundant (LEA) protein family. These LEA family proteins protect other proteins and confer resistance to dehydration, salinity and cold stress. Upregulation of seven ABA-responsive, three ethylene-responsive, and two heat shock responsive transcription factors was also observed. There were also ABA transcription factor binding sites in 30 of the upregulated genes, while 119 had a bind site for ethyleneresponsive transcription factors. This pathway matches the ABA or environment triggered, calcium-dependent signal pathway observed in maturing seeds, reinforcing the similarity of turions and seeds on a molecular, invisible level. 
Table 2. Response of duckweed to exposure to different conditions

\begin{tabular}{|c|c|c|c|c|}
\hline S. N. & Exposure & Response & Duckweed species & Reference \\
\hline 1. & $\begin{array}{c}\text { Silencing of } \mathrm{CH} 42, \text { a } \\
\text { magnesium chelatase subunit, } \\
\text { using amiRNA platform }\end{array}$ & Reduction of chlorophyll pigmentation. & L. minor & [69] \\
\hline 2. & $\begin{array}{c}\text { Overexpression of Arabidopsis } \\
\text { photorespiratory pathway gene } \\
\text { serine glyoxylate } \\
\text { aminotransferase (SGAT), } \\
\text { named as AtAGT1 }\end{array}$ & $\begin{array}{l}\text { Promote salt tolerance in duckweeds and solve the freshwater } \\
\text { salinity problems. }\end{array}$ & L. minor & [70] \\
\hline 3. & Cadmium stress & $\begin{array}{l}\text { Genes involved in DNA repair acted as an early response, } \\
\text { RNA and protein metabolism would likely respond, genes } \\
\text { involved in sulphur and reactive oxygen species (ROS) } \\
\text { metabolism were upregulated, Vacuolar sequestration. }\end{array}$ & L. punctata 6001 & [71] \\
\hline 4. & $\mathrm{NH}_{4}{ }^{+}$toxicity & $\begin{array}{l}\text { Lignin biosynthesis related genes in the phenylpropanoid } \\
\text { biosynthesis pathway were up-regulated, accumulation of } \\
\text { ROS which can cause oxidative damage leading to cell death, } \\
\text { antioxidant enzyme system was also activated. }\end{array}$ & L. minor & [72] \\
\hline 5. & Ionizing radiation (IR) & $\begin{array}{c}\text { Lower dose rates - trigger acclimation responses. } \\
\text { Higher dose rates - genes related to antioxidative defence } \\
\text { systems in terms of DNA repair and cell cycle were highly } \\
\text { expressed. }\end{array}$ & L. minor & [73] \\
\hline 6. & Abscisic acid & $\begin{array}{l}\text { Induced irreversible turion development and an increase of } \\
\text { two enzymes involved in starch and cell wall production in } \\
\text { Spirodela fronds. }\end{array}$ & Spirodela sp. & [74] \\
\hline
\end{tabular}

\section{Non- living/dried duckweed biomass}

Successive use of dried and dead plant biomass (as simple biosorbent substance) to remove the metals from water has gained popularity over the past few years, because it has high efficiency in detoxifying dilute effluents, not effected by toxic wastes, minimize the volume of chemical and/or biological sludge to be disposed off, it has no nutrient requirements, and it is cost-effective, natural and easy to transport and handle [75 81]. The dried duckweed biomass shows a porous structure with free spaces. In addition, duckweed possess diverse functional groups, namely carboxyl, amide, thiol and hydroxyl, which can be a potential binder for heavy metals, like arsenic and lead [82, 83]. The adsorption capacity of dried duckweed biomasses is listed in Table 3. The dried $S$. polyrhiza was examined and found out to be an efficient adsorbent to eliminate the basic dye of methylene blue from aqueous solution [84]. In the evaluation by Romero-Guzmán et al. [82], dead biomass of L. minor retained As(V) more strongly than E. crassipes. Dried biomass of $S$. intermedia, $L$. minor and $P$. stratiotes were investigated for simultaneous removal of metals $\left(\mathrm{Cd}^{2+}, \mathrm{Ni}^{2+}, \mathrm{Cu}^{2+}, \mathrm{Zn}^{2+}\right.$ and $\mathrm{Pb}^{2+}$ ) from wastewater derived from industrial activities. The studied biomasses removed lead and cadmium efficiently and L. minor biomass presented the highest mean removal percentage, whereas $P$. stratiotes had the lowest results for all metals tested [85]. Tang et al. [83] indicated dried biomass of $L$. punctata and $S$. polyrhiza to be promising adsorbents that may be used as alternative approaches for $\mathrm{Pb}^{2+}$ removal from contaminated water. Further studies have suggested that dried powder of $L$. aequinoctialis and $L$. perpusilla effectively removes lead from aqueous solution [86, 87]. Untreated dry powder of $L$. aequinoctialis has also proved to be a convincing adsorbent for cadmium [88]. Besides, L. minor powder has also exhibited excellent removal capability for both inorganic and organic mercury [89]. Methyl parathion and cadmium were successfully removed by $L$. gibba powder [90]. Younis et al. [91] evaluated that duckweed $L$. gibba L. could be used as low-cost biosorbent for removal of phenol ions from industrial wastewater. Upatham et al. [92] examined the effects of concentration and $\mathrm{pH}$ of solution on the biosorption of cadmium and chromium by using dry $W$. globosa biomass. The maximum adsorption of cadmium was observed at an initial $\mathrm{pH}$ of 7 which diminished with decreasing $\mathrm{pH}$ as cadmium and hydrogen $\left(\mathrm{H}^{+}\right)$ ions compete for active sites of $W$. globosa at lower $\mathrm{pH}$. Adsorption of chromium decreased with increasing $\mathrm{pH}$, because increase in $\mathrm{pH}$ would favour the formation of chromate $\left(\mathrm{CrO}_{4}{ }^{2}\right)$ ions that are not readily adsorbed by 
W. globosa. In a study on dried powder of the Landoltia punctata duckweed to remove iodate $\left(\mathrm{IO}_{3}^{-}\right)$from aqueous solutions it was discerned that $\mathrm{IO}_{3}{ }^{-}$is reduced to iodine $\left(\mathrm{I}_{2}\right)$ and I by hydroxyl groups, thereby demonstrating duckweed (Landoltia punctata) as a promising biosorbent for remediation of radioactive iodine pollution [93]. Nie et al. [94] used Landoltia punctata as a biosorbent to remove uranium dioxide $\left(\mathrm{UO}_{2}{ }^{2+}\right)$ from aqueous solutions. The maximum sorption capacity was $131.8 \mathrm{mg} / \mathrm{g}$ dry matter. Moreover, studies have conveyed that melamine treated $L$. minor has higher adsorption capacity than untreated $L$. minor for thorium (IV) biosorption under the condition of optimization [95].

Table 3. Adsorption capacity of different duckweed adsorbents

\begin{tabular}{|c|c|c|c|c|c|c|}
\hline $\begin{array}{c}\text { S. } \\
\text { N. }\end{array}$ & $\begin{array}{c}\text { Duckweed } \\
\text { species }\end{array}$ & $\mathrm{pH}$ & $\begin{array}{c}\text { Temp. } \\
(\mathrm{K})\end{array}$ & Metal & $\begin{array}{c}\mathrm{Q}_{\mathrm{m}} \\
\text { (adsorption } \\
\text { capacity) } \\
\text { mg/g DW }\end{array}$ & Ref. \\
\hline 1. & L. punctate & 4.6 & 298.15 & Lead & 250 & {$[82]$} \\
\hline 2. & S. polyrhiza & 4.6 & 298.15 & Lead & 200 & {$[82]$} \\
\hline 3. & $\begin{array}{c}\text { L. perpusilla } \\
\text { Torr. }\end{array}$ & 4.6 & 298.15 & Lead & 87 & {$[86]$} \\
\hline 4. & L. aequinoctialis & 4 & 298.15 & Lead & 57 & {$[85]$} \\
\hline 5. & W. globosa & 7 & 298.15 & Cadmium & 80.65 & {$[92]$} \\
\hline 6. & W. globosa & 1.5 & 298.15 & Chromium & 73.53 & {$[92]$} \\
\hline 7. & $\begin{array}{c}\text { Melamine } \\
\text { treated L. minor }\end{array}$ & 5.5 & - & Thorium & 129.88 & {$[95]$} \\
\hline
\end{tabular}

\section{MECHANISM OF DUCKWEED PHYTOREMEDIATION}

Heavy metals are highly pernicious and cannot be chemically degraded. Certain plant species have the ability to accumulate heavy metal in roots and then in above ground plant biomass. Plants may exude organic acids and protons making ionic species present in media biologically available for biosurfactants and chelators [96 - 100]. These ionic species bind with chelators and then pass through cellular membranes more easily [101, 102]. These contaminants are transported through the plant via apoplastic and symplastic and/or transmembrane pathways [96, 98, 103, 104]. After transportation, metals are sequestered in the cell walls, vacuoles and/or Golgi complexes [104]. This mechanism of contaminant removal is called direct phytoremediation. Although plants do not remove the contaminants in explanta phytoremediation, they stabilize them with the association of selective microorganisms and decrease the risk of potential receptors (plants as well as animals) [96, 103, 105 - 107]. Duckweeds are well recognized for their capability to eliminate the metals from the contaminated environment [41, 108, 109]. Active transport of heavy metals in freefloating aquatic plants occur through roots from where metals are transferred to other plant organs. Passive transport is associated with the direct contact of the plant body with the pollution medium [110]. A comparative analysis of uptake and detoxification mechanisms in different species of duckweed is summarized in Table 4.

\section{MAJOR APPLICATIONS OF DUCKWEED}

Due to duckweed's remarkable capability to quickly absorb nitrogen, phosphorus and other nutrients, scientists are currently exploring ways that duckweed can convert agricultural and municipal wastewater into clean water. Subsequently, biomass produced can be used for feed applications or biofuel if it was used to treat harmful industrial wastewater.

\section{Water treatment}

Global distribution, tolerance of ammonia, heavy metals, other stresses, high yield of biomass (especially at $20-30{ }^{\circ} \mathrm{C}$ ), ease of harvest, high protein and starch content, and a wide range of uses make duckweeds suitable for treating agricultural, municipal, and even industrial wastewater. The classic example of a duckweed treatment system and feed application would be the Mirzapur Bangladesh hospital wastewater facility, which was designed by the PRISM group, monitored from 1989 to 1991 [113]. Professor Zhao Hai's group from Chengdu Institute of Biology, Chinese Academy of Sciences, also has extensive records from their pilot plant at Dianchi Lake, in subtropical Yunnan, China [114] (Figure 1). 
Table 4. Uptake and detoxification mechanism of different duckweed species

\begin{tabular}{|c|c|c|c|c|c|c|}
\hline S. N. & $\begin{array}{l}\text { Duckweed } \\
\text { species }\end{array}$ & Metal & Uptake mechanism & Toxic effects & $\begin{array}{l}\text { Detoxification } \\
\text { mechanism }\end{array}$ & Reference \\
\hline 1. & L. minor & Iron & $\begin{array}{l}\text { Biosorption \& } \\
\text { bioadsorption. }\end{array}$ & $\begin{array}{l}\text { Hydroxyl radicals generated } \\
\text { through Fenton reaction } \\
\text { caused membrane } \\
\text { disintegration and cell death. } \\
\text { Roots gained an orange - } \\
\text { brownish colour due to } \\
\text { formation of iron plague. }\end{array}$ & $\begin{array}{l}\text { Subset of genes related } \\
\text { to Fe homeostasis \& } \\
\text { those coding for ferritin } \\
\text { (protein involved in Fe } \\
\text { storage) are activated. } \\
\text { Vacuoles store Fe to } \\
\text { avoid cytotoxicity. }\end{array}$ & [42] \\
\hline 2. & S. polyrhiza & Chromium & $\begin{array}{l}\mathrm{CrO}_{4}^{-2} \text { transported by } \\
\text { phosphate - sulphate } \\
\text { carrier (active } \\
\text { transport). }\end{array}$ & - & $\begin{array}{l}\text { Accumulated and } \\
\text { translocated through } \\
\text { symplast in a manner } \\
\text { that does not disrupt } \\
\text { cytoplasmic function. }\end{array}$ & [47] \\
\hline 3. & W. globosa & Arsenic & $\begin{array}{l}\text { Phosphate transporters } \\
\text { participate in As(V) } \\
\text { uptake - active } \\
\text { transport \& some } \\
\text { aquaporin channels } \\
\text { might participate in As } \\
\text { (III) uptake - passive } \\
\text { transport. }\end{array}$ & $\begin{array}{l}\text { Arsenate uptake, but } \\
\text { concurrent production of } \\
\text { arsenite. }\end{array}$ & - & [52] \\
\hline 4. & W. globosa & Cadmium & $\begin{array}{c}\text { Mainly passive } \\
\text { adsorption via apoplast } \\
\text { component (due to cell } \\
\text { binding). }\end{array}$ & $\begin{array}{l}\text { Homeostasis interference due } \\
\text { to high amounts of cadmium } \\
\text { actively taken up by the plant } \\
\text { cells when cell binding } \\
\text { capacity was saturated. } \\
\end{array}$ & - & [54] \\
\hline 5. & L. minor & Lead and zinc & - & $\begin{array}{l}\text { Interference with the } \\
\text { photosystem resultantly } \\
\text { inducing chlorosis, decrease in } \\
\text { soluble protein content, } \\
\text { decrease in chlorophyll a and } \\
\text { carotenoid content. }\end{array}$ & $\begin{array}{l}\text { Catalase (CAT) activity } \\
\text { increased, CAT acts on } \\
\text { hydrogen peroxide } \\
\left(\mathrm{H}_{2} \mathrm{O}_{2}\right) \text { and converts it to } \\
\text { water and oxygen. } \\
\text { Increase in enzyme } \\
\text { activity. } \\
\end{array}$ & [111] \\
\hline 6. & L. minor & Cadmium & - & $\begin{array}{l}\text { Root elongation \& frond no. } \\
\text { decreased, Hormesis response } \\
\text { seen. Influences antioxidant } \\
\text { system (mainly CAT). }\end{array}$ & $\begin{array}{l}\text { High Cd tolerance can } \\
\text { be attributed to an } \\
\text { increase in Cd inactive } \\
\text { forms. At lower } \\
\text { concentrations Cd stress } \\
\text { activate peroxidases } \\
\text { (POD), superoxide } \\
\text { dismutase (SOD), total } \\
\text { antioxidant capacity (T- } \\
\text { AOC) and } \\
\text { malondialdehyde } \\
\text { (MDA). }\end{array}$ & [112] \\
\hline
\end{tabular}

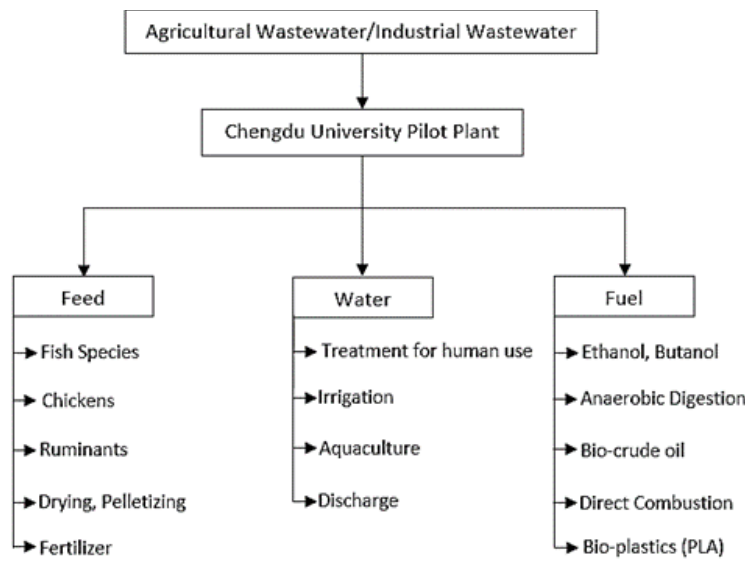

Figure 1. Flowchart of duckweed wastewater treatment and biomass application [114]

\section{Bioenergy}

Bioenergy applications of duckweed are discussed in Figure 2. Duckweed biomass exhibits good characteristics for bioethanol production due to its relatively high starch and low lignin percentage. The first commercially viable example of ethanol fermentation, the Andrew Young Foundation conducted a private research trial using the ecosystem technology, produced by resource recovery experts Greenbelt Resources Corporation, which was presented in a feasibility study report conducted by an independent agency and submitted to the United States Department of Agriculture (USDA) in 2017. With 
successful feasibility determined, the foundation created a corporation called Duckweed Days LLC (Limited Liability Company), which partnered with Greenbelt Resources to conduct a pilot system development project in Paso Robles, California, USA, in 2018. Leveraging its farming and agricultural expertise as well as its engineering prowess, Greenbelt has developed a species agnostic prototype cultivation, harvesting and processing system.

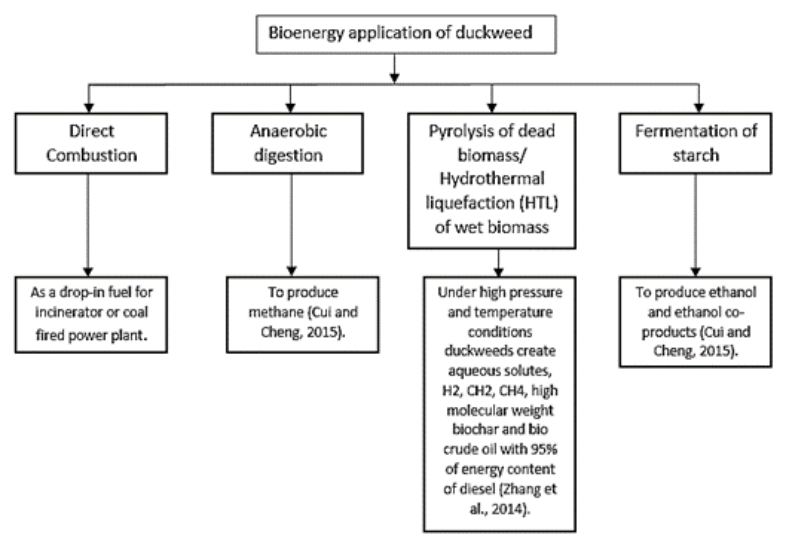

Figure 2. Bioenergy applications of duckweed [115]

\section{Animal feed}

Duckweed can recycle nutrients back into the food supply, provided it is monitored for heavy metals and other hazards, and legally approved. Agriquatics wastewater treatment proposed blueprint for a municipal treatment facility designed by Agriquatics. The systems start with solids removal through laminar flow separators and hydrocyclones, and transport solids to an array of bacterial digesters. A series of duckweed ponds remove solutes and their circular shape facilitates central harvesting. Water is then filtered and disinfected with conventional methods. Duckweed biomass can be tested, sterilized, and converted to Tilapia fish feed [115]. Duckweeds have been a traditional feed for fish and poultry in South-East Asia for centuries. Duckweed was found to be beneficial in replacing $\sim 15 \%$ of the soybean meal in the feed for chickens or broilers, and $40 \%$ in the case of laying hens [113, 116]. Finally, ruminants have shown promising results with high nitrogen digestibility in merino sheep, and cattle consuming and effectively digesting up to $10 \%$ of their weight in dried duckweed per day [116].

\section{Human nutrition}

The Wolffia genus of the duckweed family has been traditional cuisine in Thailand, Burma and Laos for centuries, since Wolffia in its plant tissue do not produce calcium oxalate crystals, a causative agent of human kidney stones. At present, there are three large companies producing Wolffia or Lemna for human consumption, namely Hinoman, Parabel and Green Onyx (Table 5).

Table 5. Companies producing duckweed for human consumption [115]

\begin{tabular}{|c|c|c|c|}
\hline $\begin{array}{l}\text { S. } \\
\text { N. }\end{array}$ & Company & Strategy & Product \\
\hline 1. & Hinoman & $\begin{array}{l}\text { Greenhouse } \\
\text { precision } \\
\text { agriculture } \\
\text { cultivation. }\end{array}$ & $\begin{array}{l}\text { Wolffia with } 25 \% \text { carbohydrate } \\
\text { content, } 45 \% \text { protein content } \\
\text { and a complete and bioavailable } \\
\text { amino acid profile, such as egg } \\
\text { or soy, with a higher Protein } \\
\text { digestibility-corrected amino } \\
\text { acid score (PDCAAS) than soy. }\end{array}$ \\
\hline 2. & Parabel & $\begin{array}{l}\text { Open pond Lemna } \\
\text { cultivation and } \\
\text { protein extraction. }\end{array}$ & Protein powder. \\
\hline 3. & Green Onyx & $\begin{array}{l}\text { Developed robotic } \\
\text { farming systems. }\end{array}$ & Dispense Wolffia on demand. \\
\hline 4. & $\begin{array}{l}\text { Plantible } \\
\text { Foods }\end{array}$ & $\begin{array}{l}\text { Developing a } \\
\text { gentle protein } \\
\text { isolation process } \\
\text { using Lemna. }\end{array}$ & $\begin{array}{c}\text { Colourless, tasteless protein } \\
\text { isolate with physical properties } \\
\text { of egg whites to create a vegan } \\
\text { product. }\end{array}$ \\
\hline
\end{tabular}

\section{Phosphorous reclamation}

Economically mineable, organically available phosphorous is expected to be scarce by 2050 or 2100 , and production might decline by 2030, raising its price possibly beyond the reach of poorer farmers [117]. Fortunately, phosphorous can be recycled by better farming practices or by using more aquatic plants and other methods to recapture more than the current rate of $50 \%$ from human wastes.

\section{As a life support system}

Duckweed was additionally described as one of the most attractive higher plants for long- 
duration supporting human life in space [118]. National Aeronautics and Space Administration (NASA) is interested in developing closed-loop life support systems for long-term missions. L. aequinoctialis was found to have a $32 \%$ increase in growth rate in simulated microgravity [118]. Therefore, Space Lab Technologies, LLC is currently collaborating with the University of Colorado at Boulder on a Phase 2 grant from NASA to develop the $\mu \mathrm{G}$-LilyPond ${ }^{\mathrm{TM}}$ growth chamber as part of a life support system [115]. Presently the system is designed to provide fresh food and oxygen, with the eventual goal of converting urine to clean water.

\section{Medicine}

There have been academic papers reporting over 20 transgenic therapeutic proteins in duckweed reaching as high as $7 \%$ of total soluble protein [119]. Given the lower cost of production and lower risk of transmissible pathogens compared to mammalian cell lines, duckweed may provide genetically engineered proteins for medical or other applications. $L$. minor can be used for synthesis of recombinant proteins [120]. L. punctata is rich in flavonoids [121] and used in traditional Chinese medicine. It has also potential for pharmaceutical drugs.

\section{DUCKWEED DISPOSAL}

Appropriate phytoremediation technology needs intervallic harvesting of the plant biomass in order to assimilate and confiscate heavy metals and nutrients from water bodies. Conversion of biomass into superior material is a significant factor in promoting this technique. Many studies have reported that aquatic plants like duckweed biomass after phytoremediation can be used as animal feed and in biogas production [122] (Figure 3). Rolli et al. [48] recommend that harvested biomass may be used for composting and as a supplement to fertilizers. Dry biomass of $L$. minor generated during phytoremediation of iron, without other toxic metals, could be an important fertilizer for iron-deficient soils, which comprise one-third of the world's soils [42]. Dushenkov et al. [123] have pointed out that the high water content of aquatic plants impedes the drying, composting, or incineration process. Dried duckweed can be used as a drop-in fuel for a trash incinerator or coal-fired power plant. This would concentrate heavy metals in the smoke, which could be scrubbed, and ash can be properly disposed or encapsulated for reuse in concrete or gypsum [115].

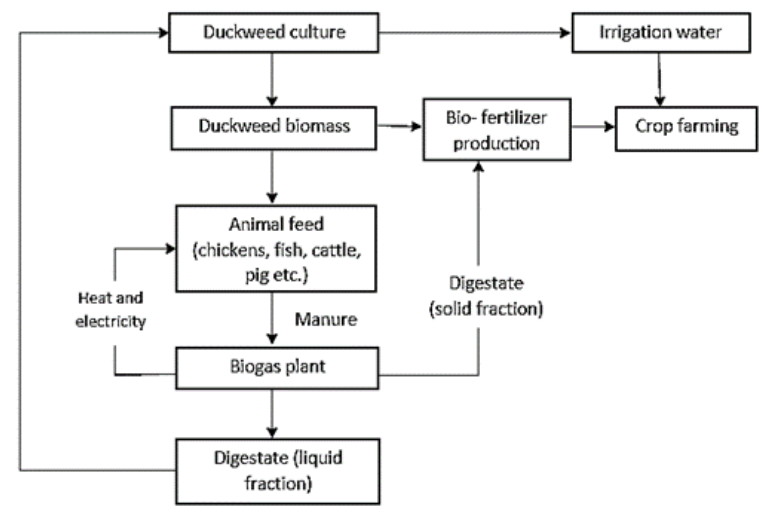

Figure 3. Schematic presentation of duckweed disposal [124]

\section{CONCLUSION}

Heavy metal pollution is a major environmental concern for which conventional remediation approaches prove unfulfilling. Utilization of phytoremediation seems to be less destructive, economical, and environmentally sound clean-up technology. Duckweed has been reported to be very useful in phytoremediation of organic matter, suspended solids, heavy metals and soluble salt from wastewater. Application of duckweed both in bioaccumulation (with living plant biomass) and bio-sorption (with dead plant biomass) can be done successfully for the elimination of heavy metals. Comprehensive interaction, transport and chelating activities regulate the storage and accumulation of heavy metals by the duckweed. Plant biomass can be used later on for production of biogas, as fertilizer and as animal feed. Genetic engineering of duckweed 
to enhance its heavy metal uptake capacity is in its preliminary phases. Due to their high biomass, accumulation rate and nutrient content duckweeds have increasingly been considered as bioenergy and food source, as response to global resources exploitation and environmental crisis. The present review highlights the benefits of using duckweed to treat water contaminated with heavy metals, which are currently limited to laboratory experiments and batch systems and are rarely on microcosm and mesocosm scale. The novel abilities of duckweed in various fields can be enriched by the use of genetic engineering. Thus, duckweed is a promising plant resource which deserves further research and development.

\section{REFERENCES}

[1] S.S. Ahluwalia, D. Goyal, Microbial and plant derived biomass for removal of heavy metals from wastewater, Bioresource Technology 98(2007), 2243-2257.

https://doi.org/10.1016/j.biortech.2005.1 2.006

[2] E.L. Arthur, P.J. Rice, P.J. Rice, T.A. Anderson, S.M. Balodi, K.L.D. Henderson, J.R. Coats, Phytoremediation - An overview, Critical Reviews in Plant Sciences 24(2005) 2, 109-122. https://doi.org/10.1080/07352680590952 496

[3] S.D. Cunningham, W.R. Berti, J.W.W. Huang, Phytoremediation of contaminated soils, Trends in Biotechnology 13(1995), 393-397. https://doi.org/10.1016/S01677799(00)88987-8

[4] O.V. Singh, S. Labana, G. Pandey, R. Budhiraja, R.K. Jain, Phytoremediation: An overview of metallic ion decontamination from soil, Applied Microbiology and Biotechnology 61(2003) 5-6, 405-412. https://doi.org/10.1007/s00253-0031244-4

[5] M. Varkey, N. Lal, Z.H. Khan, Phytoremediation: Strategies to Enhance the Potential for Toxic Metal Remediation of Brassica Oilseed Species, in: Phytotechnologies: Remediation of Environmental Contaminants, ed. N.A. Anjum, M.E. Periera, I. Ahmad, A.C. Durate, S. Umar, N.A. Khan, CRC Press/Taylor and Francis Group, USA, 2012, 293-308.

[6] H. Xia, X. Ma, Phytoremediation of ethion by water hyacinth (Eichhornia crassipes) from water, Bioresource Technology 97(2006) 8, 1050-1054. https://doi.org/10.1016/j.biortech.2005.0 $\underline{4.039}$

[7] X. Yang, Y. Feng, Z. He, P.J. Stoffella, Molecular mechanisms of heavy metal hyperaccumulation and phytoremediation, Journal of Trace Elements in Medicine and Biology 18(2005) 4, 339-353. https://doi.org/10.1016/i.jtemb.2005.02.0 $\underline{07}$

[8] M. Rafati, N. Khorasani, F. Moattar, A. Shirvany, F. Moraghebi, S. Hosseinzadeh, Phytofiltration potential of Populus alba and Morus alba for cadmium, chromium and nickel adsorption from polluted soil, International Journal of Environmental Research 5(2011), 961-970. https://doi.org/10.22059/ijer.2011.453

[9] B.K. Yadav, M.A. Siebel, J.J.A. Bruggen, Rhizofiltration potential of a heavy metal (lead) containing wastewater using the wetland plant Carex pendula, CLEAN - Soil, Air, Water 39(2011) 5, 467-474. https://doi.org/10.1002/clen.201000385

[10] B.R. Glick, Phytoremediation: Synergistic use of plants and bacteria to clean up the environment, Biotechnology Advances 21(2003) 5, 383-393. https://doi.org/10.1016/S07349750(03)00055-7

[11] R.L. Chaney, M. Malik, Y.M. Li, S.L. Brown, E.P. Brewer, J.S. Angle, A.J. Baker, Phytoremediation of soil metals, Current Opinion in Biotechnology 8(1997) 3, 279-284. https://doi.org/10.1016/S09581669(97)80004-3 
[12] N. Khellaf, M. Zerdaoui, Phytoaccumulation of zinc by the aquatic plant, Lemna gibba L., Bioresource Technology 100(2009), 6137-6140.

https://doi.org/10.1016/j.biortech.2009.0 $\underline{6.043}$

[13] V.C. Pandey, Phytoremediation of heavy metals from fly ash pond by Azolla caroliniana, Ecotoxicology and Environmental Safety 82(2012), 8-12. https://doi.org/10.1016/j.ecoenv.2012.05 .002

[14] A. Sood, P.L. Uniyal, R. Prasanna, A.S. Ahluwalia, Phytoremediation potential of aquatic macrophyte Azolla, AMBIO 41(2012) 2, 122-137. https://doi.org/10.1007\%2Fs13280-0110159-z

[15] A.L. Charles, S.J. Markich, P. Ralph, Toxicity of uranium and copper individually and in combination to a tropical freshwater macrophyte (Lemna aequinoctialis), Chemosphere 62(2006) 8 ,

1224-1233.

https://doi.org/10.1016/j.chemosphere.20 05.04 .089

[16] N.R. Axtell, S.P.K. Sternberg, K. Claussen, Lead and nickel removal using Microspora and Lemna minor, Bioresource Technology 89(2003) 1, 4148. $\quad$ https://doi.org/10.1016/S09608524(03)00034-8

[17] X. Zhang, Y. Hu, Y. Liu, B. Chen, Arsenic uptake, accumulation and phytofiltration by duckweed (Spirodela polyrhiza L.), Journal of Environmental Science 23(2011) 4, 601-606. https://doi.org/10.1016/S10010742(10)60454-8

[18] T.O. Ajayi, A.O. Ogunbayio, Achieving environmental sustainability in wastewater treatment by phytoremediation with water hyacinth (Eichhornia crassipes), Journal of Sustainable Development 59(2012) 7, 111. https://doi.org/10.5539/jsd.v5n7p80

[19] A.F.A. Bakar, I. Yusoff, N.T. Fatt, F. Othman, M.A. Ashraf, Arsenic, zinc and aluminium removal from gold mine wastewater effluents and accumulation by submerged aquatic plants (Cabomba piauhyensis, Egeria densa and Hydrilla verticillata), BioMed Research International 2013(2013), 1-7. https://doi.org/10.1155/2013/890803

[20] L.I. Cabrera, G.A. Salazar, M.W. Chase, S.J. Mayo, J. Bogner, P. Dávila, Phylogenetic relationships of Aroids and duckweeds (Araceae) inferred from coding and noncoding plastid DNA, American Journal of Botany 95(2008) 9, 1153-1165. https://doi.org/10.3732/ajb.0800073

[21] E. Landolt, R. Kandeler, The family of Lemnaceae - A Monographic study: Phytochemistry, Physiology, Application and Bibliography (vol. 2 of monograph), in: Biosystematic Investigations in The Family of Duckweeds (Lemnaceae) 4 (95), 1987, Publications of the Geobotanical Institute of the E.T.H, Zurich: Stiftung Rubel, 1-638.

[22] E. Landolt, The family of Lemnaceae - a monographic study, vol 1, in: Biosystematic investigations in the family of duckweeds (Lemnaceae), vol. 2, 71(1) 1986, Veröffentlichungen des Geobotanischen Institutes der E.T.H, Zürich: Stiftung Rubel, 566.

[23] L. Nauheimer, D. Metzler, S.S. Renner, Global history of the ancient monocot family Araceae inferred with models accounting for past continental positions and previous ranges based on fossils, New Phytologist 195(2012) 4, 938-950. https://doi.org/10.1111/j.14698137.2012.04220.x

[24] K.S. Sree, M. Bog, K.J. Appernoth, Taxonomy of duckweeds (Lemnaceae) potential new crop plants, Emirates Journal of Food and Agriculture 28(2016) 5, 291-302. https://doi.org/10.9755/ejfa.2016-01-038

[25] J. Bogner, The free floating Aroids (Araceae) - living and fossil, Zitteliana 48(2009), 113-128.

[26] J.J. Cheng, A.M. Stomp, Growing duckweed to recover nutrients from wastewaters and for production of fuel ethanol and animal feed, CLEAN - Soil, Air, Water 37(2009) 1, 17-26. https://doi.org/10.1002/clen.200800210 
[27] D. Singh, A. Tiwari, R. Gupta, Phytoremediation of lead from wastewater using aquatic plants, Journal of Agricultural Technology 8(2012) 1, 111.

[28] A. Wahab, S.S. Ismail, E.Z. Abidin, S. Praveena, Neptunia oleraceae (water mimosa) as phytoremediation plant and the risk to human health: A review, Advances in Environmental Biology 8(2014) 15, 187-194.

[29] Y. Chong, H.Y. Hu, Y. Qian, Effect of inorganic nitrogen compounds and $\mathrm{pH}$ on the growth of duckweed, Huan Jing Ke Xue 24(2003), 35-40.

[30] Y. Uysal, Removal of chromium ions from wastewater by duckweed, Lemna minor $L$. by using a pilot system with continuous flow, Journal of Hazardous Materials 263(2013), 486-492. https://doi.org/10.1016/j.jhazmat.2013.1 $\underline{0.006}$

[31] M. Thayaparan, S. Iqbal, M.C.M. Iqbal, Phytoremediation potential of Lemna minor for removal of $\mathrm{Cr}(\mathrm{VI})$ in aqueous solution at the optimum nutrient strength, Open University of Sri Lanka (OUSL) Journal 9(2015), 97-111. http://doi.org/10.4038/ouslj.v9i0.7329

[32] Y. Uysal, F. Taner, Effect of $\mathrm{pH}$, temperature, and lead concentration on the bioremoval of lead from water using Lemna minor, International Journal of Phytoremediation 11(2009) 7, 591- 608. https://doi.org/10.1080/15226510902717 $\underline{648}$

[33] L. Kaur, K. Gadgil, S. Sharma, Role of $\mathrm{pH}$ in the accumulation of lead and nickel by common duckweed (Lemna minor), International Journal of Bioassays 01(2012) 12, 191-195.

[34] B. Sekomo, D. Rousseau, A.S. Saleh, P.N.L. Lens, Heavy metal removal in duckweed and algae ponds as a polishing step for textile wastewater treatment, Ecological Engineering 44(2012), 102110.

https://doi.org/10.1016/j.ecoleng.2012.0 $\underline{3.003}$

[35] P. Bres, D. Crespo, P. Rizzo, R. La Rossa, Capacidad de las macrofitas Lemna minor y Eichhornia crassipes para eliminar el níquel (Capacity of the macrophytes Lemna minor and Eichhornia crassipes to remove nickel), Revista de Investigaciones Agropecuarias (RIA) 38(2012) 2, 153157.

[36] C.M.D.C. Marín, G. Oron, Boron removal by the duckweed Lemna gibba: A potential method for the remediation of boron-polluted waters, Water Research 41(2007), 4579-4584. https://doi.org/10.1016/j.watres.2007.06. $\underline{051}$

[37] A. Sasmaz, E. Obek, The accumulation of arsenic, uranium, and boron in Lemna gibba L. exposed to secondary effluents, Ecological Engineering 35(2009) 10, 1564-1567.

https://doi.org/10.1016/j.ecoleng.2009.0 6.007

[38] N. Jafari, M. Akhavan, Effect of $\mathrm{pH}$ and heavy metal concentration on phytoaccumulation of zinc by three duckweed species, American - Eurassian Journal of Agricultural and Environmental Science 10(2011) 1, 3441.

[39] S.S. Sharma, J.P. Gaur, Potential of Lemna polyrrhiza for the removal of heavy metal, Ecological Engineering 4(1995), $37-43$. https://doi.org/10.1016/09258574(94)00047-9

[40] N.M. Azeez, A.A. Sabbar, Efficiency of Duckweed (Lemna minor L.) in phytotreatment of wastewater pollutants from Basrah oil refinery, Journal of Applied Phytotechnology in Environmental Sanitation 1(2012) 4, 163-172.

[41] M.K. Daud, S. Ali, Z. Abbas, I.E. Zaheer, M.A. Riaz, A. Malik, A. Hussain, M. Rizwan, M.Z. Rehman, S.J. Zhu, Potential of duckweed (Lemna minor) for the phytoremediation of landfill leachate, Journal of Chemistry 2018(2018), 1-9. https://doi.org/10.1155/2018/3951540

[42] S. Teixeira, M.N. Vieira, J.E. Marques, R. Pereira, Bioremediation of an ironrich mine effluent by Lemna minor, International Journal 
Phytoremediation 16(2014) 12, 12281240.

https://doi.org/10.1080/15226514.2013.8 21454

[43] D. Chaudhuri, A. Majumdar, A. Misra, K. Bandyopadhyay, Cadmium removal by Lemna minor and Spirodela polyrhiza, International journal of phytoremediation 16(2014), 1119-1132. https://doi.org/10.1080/15226514.2013.8 $\underline{21446}$

[44] M.A. Rahman, H. Hasegawa, K. Ueda, T. Maki, C. Okumura, M.M. Rahman, Arsenic accumulation in duckweed (Spirodela polyrhiza L.): A good option for phytoremediation, Chemosphere 69(2007), 493-499.

https://doi.org/10.1016/j.chemosphere.20 07.04 .019

[45] Z. Leblebici, A. Aksoy, Growth and lead accumulation capacity of Lemna minor and Spirodela polyrhiza (Lemnaceae): interactions with nutrient enrichment, Water, Air, Soil Pollution 214(2011) 14 ,

175-184.

https://doi.org/10.1007/s11270-0100413-1

[46] C. Goswami, A. Majumder, K. Bandyopadhyay, A.K. Misra, Efficiency of Spirodela polyrhiza for removal and uptake of $\mathrm{Pb}$ and $\mathrm{Ni}$, in: Strategic Technologies of Complex Environmental Issues - A Sustainable Approach, ed. G.C. Mishra, Excellent Publishing House, New Delhi, 2014, 28 33.

[47] S. Islam, F.B. Nasir, M.A. Hoque, G.M. Munna, Chromium removal from water using Spirodela polyrhiza, Asian Journal of Applied Sciences 10(2017) 3, 145150.

https://doi.org/10.3923/ajaps.2017.145.1 $\underline{50}$

[48] N.M. Rolli, M.G. Nadagouda, B.S. Giriyappanavar, T.C. Taranath, Phytoremediation of zinc by Spirodela polyrhiza (L.) Schleiden, Nature Environment and Pollution Technology 6(2007) 1, 41-44.

[49] Z.A. Al-Balawna, Remove heavy metals $(\mathrm{Cd}$ and $\mathrm{Pb})$ from irrigation water in Jordan valley by using duckweeds
(Spirodela polyrhiza), Acta Scientific Agriculture 4(2020) 2, 1-4.

[50] A. Loveson, R. Sivalingam, R. Syamkumar, Aquatic macrophyte Spirodela polyrrhiza as a phytoremediation tool in polluted wetland water from Eloor, Ernakulam district, Kerala, IOSR Journal of Environmental Science, Toxicology and Food Technology 5(2013) 1, 51-58. https://doi.org/10.9790/2402-0515158

[51] J. Shi, Z. Xiang, T. Peng, H. Li, K. Huang, D. Liu, T. Huang, Effects of melatonin-treated Nasturtium officinale on the growth and cadmium accumulation of subsequently grown rice seedlings, International Journal of Environmental Analytical Chemistry 100(2020), 1-9. https://doi.org/10.1080/03067319.2019.1 700972

[52] X. Zhang, F.J. Zhao, Q. Huang, P.N. Williams, G.X. Sun, Y.G. Zhu, Arsenic uptake and speciation in the rootless duckweed Wolffia globosa, New Phytologist 182(2009) 2, 421-428. https://doi.org/10.1111/j.1469-

\subsubsection{8.x}

[53] P. Garg, P. Chandra, The duckweed Wolffia globosa as an indicator of heavy metal pollution: sensitivity to $\mathrm{Cr}$ and $\mathrm{Cd}$, Environmental Monitoring and Assessment 2(1994) 9, 89-95. https://doi.org/10.1007/BF00546781

[54] W.Y. Xie, Q. Huang, G. Li, C. Rensing, Y.G. Zhu, Cadmium accumulation in the rootless macrophyte Wolffia globosa and its potential for phytoremediation, International Journal of Phytoremediation 15(2013) 4, 385-397. https://doi.org/10.1080/15226514.2012.7 $\underline{02809}$

[55] M. Karkhanis, C. Jadia, M.H. Fulekar, Rhizofiltration of heavy metals from coal ash leachate, Asian Journal of Water, Environment and Pollution 3(2006) 1, 91-94.

[56] M. Roy, A.K. Giri, S. Dutta, P. Mukherjee, Integrated phytobial remediation for sustainable management of arsenic in soil and water, Environment International 75(2015), 180-198. 
https://doi.org/10.1016/j.envint.2014.11. $\underline{010}$

[57] M.S. Bora, K.P. Sarma, Phytoremediation of heavy metals/metalloids by native herbaceous macrophytes of wetlands: Current research and perspectives, in: Emerging issues in the water environment during anthropocene: A South East Asian perspective, ed. M. Kumar, D.D. Snow, R. Honda, Springer, Singapore, 2020, 261-284. https://doi.org/10.1007/978981-32-9771-5 14

[58] W. Wang, J. Messing, Status of duckweed genomics and transcriptomics, Plant Biology 17(2015) 1, 10-15. https://doi.org/10.1111/plb.12201

[59] W. Wang, G. Haberer, H. Gundlach, C. Gläßer, T. Nussbaumer, M.C. Luo, A. Lomsadze, M. Borodovsky, R.A. Kerstetter, J. Shanklin, D.W. Byrant, T.C. Mockler, K.J. Appenroth, J. Grimwood, J. Jenkins, J. Chow, C. Choi, C. Adam, X.H. Cao, J. Messing, The Spirodela polyrhiza genome reveals insights into its neotenous reduction fast growth and aquatic lifestyle, Nature Communications 5(2014), 1-13. https://doi.org/10.1038/ncomms4311

[60] W. Wang, R.A. Kerstetter, T.P. Michael, Evolution of genome size in duckweeds (Lemnaceae), Journal of Botany 2011(2011), 1-9. https://doi.org/10.1155/2011/570319

[61] K.J. Appenroth, D.J. Crawford, D.H. Les, After the genome sequencing of duckweed - How to proceed with research on the fastest growing angiosperm?, Plant Biology (Stuttgart) 17(2015) (Suppl. 1), 1-4. https://doi.org/10.1111/plb.12248

[62] T.Y. Li, Z.T. Xiong, Cadmium-induced colony disintegration of duckweed (Lemna paucicostata Hegelm.) and as biomarker of phytotoxicity, Ecotoxicology and Environmental Safety 59(2004) 2, 174-179. https://doi.org/10.1016/j.ecoenv.2003.11 .007

[63] R. Vunsh, U. Heinig, S. Malitsky, A. Aharoni, A. Avidov, A. Lerner, M. Edelman, Manipulating duckweed through genome duplication, Plant Biology 17(2015) 1, 115-119. https://doi.org/10.1111/plb.12212

[64] J. Li, M. Jain, R. Vunsh, J. Vishnevetsky, U. Hanania, M. Flaishman, A. Perl, M. Edelman, Callus induction and regeneration in Spirodela and Lemna, Plant Cell Reports 22(2004) 7 , 457-464. https://doi.org/10.1007/s00299-0030724-4

[65] R. Vunsh, J. Li, U. Hanania, M. Edelman, M. Flaishman, A. Perl, J.P. Wisniewski, G. Freyssinet, High expression of transgene protein in Spirodela, Plant Cell Reports 26(2007) 9, 1511-1519. https://doi.org/10.1007/s00299-0070361-4

[66] A.M. Stomp, The duckweeds: A valuable plant for biomanufacturing, Biotechnology Annual Review 11(2005), 69-99. https://doi.org/10.1016/S13872656(05)11002-3

[67] Y.T. Yamamoto, N. Rajbhandari, X. Lin, B.A. Bergmann, Y. Nishimura, A.M. Stomp, Genetic transformation of duckweed Lemna gibba and Lemna minor, In Vitro Cellular and Developmental Biology - Plant 37(2001) 3 , 349-353.

https://doi.org/10.1007/s11627-0010062-6

[68] J. Yang, S. Hu, G. Li, S. Khan, S. Kumar, L. Yao, P. Duan, H. Hou, Transformation development in duckweed, in: The Duckweed Genomes, ed. X.H. Cao, P. Fourounjian, W. Wang, Springer Nature, Switzerland, 2020, 143 155. https://doi.org/10.1007/978-3-03011045-1_15

[69] A. Canto-Pastor, A. Mollá-Morales, E. Ernst, W. Dahl, J. Zhai, Y. Yan, B.C. Meyers, J. Shanklin, R. Martienssen, Efficient transformation and artificial miRNA gene silencing in Lemna minor, Plant Biology (Stuttgart) 17(2015) (Suppl. 1), 59-65. https://doi.org/10.1111/plb.12215

[70] L. Yang, H. Han, M. Liu, Z. Zuo, K. Zhou, J. Lü, Y. Zhu, Y. Bai, Y. Wang, 
Overexpression of the Arabidopsis, photorespiratory pathway gene, serine: glyoxylate aminotransferase (AtAGT1), leads to salt stress tolerance in transgenic duckweed (Lemna minor), Plant Cell Tissue Organ Culture 113(2013) 3, 407416. https://doi.org/10.1007/s11240-012$\underline{0280-0}$

[71] H. Xu, C. Yu, X. Xia, M. Li, H. Li, Y. Wang, S. Wang, C. Wang, Y. Ma, G. Zhou, Comparative transcriptome analysis of duckweed (Landoltia punctata) in response to cadmium provides insights into molecular mechanisms underlying hyperaccumulation, Chemosphere 190(2018), 154-165. https://doi.org/10.1016/j.chemosphere.20 17.09 .146

[72] W. Wang, R. Li, Q. Zhu, X. Tang, Q. Zhao, Transcriptomic and physiological analysis of common duckweed Lemna minor responses to $\mathrm{NH}_{4}{ }^{+}$toxicity, BMC Plant Biology 16(2016) 1, Article number: 92. https://doi.org/10.1186/s12870-0160774-8

[73] A. Van Hoeck, N. Horemans, R. Nauts, M. Van Hees, H. Vandenhove, R. Blust, Lemna minor plants chronically exposed to ionising radiation: RNA-seq analysis indicates a dose rate dependent shift from acclimation to survival strategies, Plant Science 257(2017), 84-95. https://doi.org/10.1016/j.plantsci.2017.0 $\underline{1.010}$

[74] W. Wang, Y. Wu, J. Messing, RNA-Seq transcriptome analysis of Spirodela dormancy without reproduction, BMC Genomics 15(2014) 1, Article number: 60. https://doi.org/10.1186/1471-2164$15-60$

[75] Z. Han, Z. Guo, Y. Zhang, X. Xiao, Z. $\mathrm{Xu}, \quad \mathrm{Y}$. Sun, Adsorption-pyrolysis technology for recovering heavy metals in solution using contaminated biomass phytoremediation, Resources, Conservation, Recycling 129(2018), 2026.

https://doi.org/10.1016/j.resconrec.2017. $\underline{10.003}$
[76] P. Kaewsarn, Biosorption of copper (II) from aqueous solutions by pre-treated biomass of marine algae Padina sp., Chemosphere 47(2002) 10, 1081-1085. https://doi.org/10.1016/S00456535(01)00324-1

[77] F. Veglio, F. Beolchini, Removal of heavy metal ions by biosoprtion: a review, Hydrometallurgy 44(1997) 3, 301-316. https://doi.org/10.1016/S0304386X(96)00059-X

[78] I.A.H. Schneider, J. Rubio, Sorption of heavy metals by the nonliving biomass of freshwater macrophytes, Environmental Science and Technology 33(1999) 13, 2213-2217. https://doi.org/10.1021/es981090z

[79] I.A.H. Schneider, J. Rubio, R. Smith, Biosorption of metals onto plant biomass: exchange adsorption or surface precipitation?, International Journal of Mineral Processing 62(2001) (1-4), 111120. https://doi.org/10.1016/S03017516(00)00047-8

[80] H. Elifantz, E. Tel-Or, Heavy metal biosorption by plant biomass of the macrophyte Ludwigia stolonifera, Water Air and Soil Pollution 141(2002), 207218.

https://doi.org/10.1023/A:102134380422 $\underline{0}$

[81] S. Abbaszadeh, S.R. Wan Alwi, C. Webb, N. Ghasemi, I.I. Muhamad, Treatment of lead-contaminated water using activated carbon adsorbent from locally available papaya peel biowaste, Journal of Cleaner Production 118(2016), 210-222. https://doi.org/10.1016/j.jclepro.2016.01. $\underline{054}$

[82] E.T. Romero-Guzmán, L.R. ReyesGutiérrez, M.J. Marín-Allende, Z.I. González-Acevedo, M.T. OlguínGutiérrez, Physicochemical properties of non-living water hyacinth (Eichhornia crassipes) and lesser duckweed (Lemna minor) and their influence on the $\mathrm{As}(\mathrm{V})$ adsorption processes, Chemistry and Ecology 29(2013) 5, 459-475. https://doi.org/10.1080/02757540.2013.7 72589 
[83] J. Tang, Y. Li, X. Wang, M. Daroch, Effective adsorption of aqueous $\mathrm{Pb}^{2+}$ by dried biomass of Landoltia punctata and Spirodela polyrhiza, Journal of Cleaner Production 145(2017), 25-34. https://doi.org/10.1016/j.jclepro.2017.01. $\underline{038}$

[84] P. Waranusantigul, P. Pokethitiyook, M. Kruatrachue, E.S. Upatham, Kinetics of basic dye (methylene blue) biosorption by giant duckweed (Spirodela polyrrhiza), Environmental Pollution 125(2003) 3, 385-392. https://doi.org/10.1016/S02697491(03)00107-6

[85] P. Miretzky, A. Saralegui, A.F. Cirelli, Simultaneous heavy metal removal mechanism by dead macrophytes, Chemosphere 62(2006) 2, 247-254. https://doi.org/10.1016/j.chemosphere.20 $\underline{05.05 .010}$

[86] L. Chen, Y. Fang, Y. Jin, Q. Chen, Y. Zhao, Y. Xiao, H. Zhao, Biosorption of $\mathrm{Pb}^{2+}$ by dried powder of duckweed (Lemna aequinoctialis), Chinese Journal of Applied Environmental Biology 19(2013) 6, 1046-1052. http://doi.org/10.3724/SP.J.1145.2013.0 1046

[87] Y. Tang, L. Chen, X. Wei, Q. Yao, T. Li, Removal of lead ions from aqueous solution by the dried aquatic plant, Lemna perpusilla Torr., Journal of Hazardous Materials 244-245(2013), 603-612.

https://doi.org/10.1016/j.jhazmat.2012.1 0.047

[88] L. Chen, Y. Fang, Y. Jin, Q. Chen, Y. Zhao, Y. Xiao, H. Zhao, Biosorption of $\mathrm{Cd}^{2+}$ by untreated dried powder of duckweed Lemna aequinoctialis, Desalination and Water Treatment 53(2015) $\quad 1, \quad 183-194$. https://doi.org/10.1080/19443994.2013.8 39399

[89] S-X. Li, F-Y. Zheng, H. Yang, J-C. Ni, Thorough removal of inorganic and organic mercury from aqueous solutions by adsorption on Lemna minor powder, Journal of Hazardous Materials 186(2011) $\quad 1, \quad 423-429$. https://doi.org/10.1016/j.jhazmat.2010.1 $\underline{1.009}$

[90] F.Z. Halaimi, Y. Kellali, M. Couderchet, S. Semsari, Comparison of biosorption and phytoremediation of cadmium and methyl parathion, a case-study with live Lemna gibba L. and Lemna gibba powder, Ecotoxicology and Environmental Safety 105(2014), 112120.

https://doi.org/10.1016/j.ecoenv.2014.02 .002

[91] A.M. Younis, E.M.A. Nafea, Y.I. Mosleh, M.S. Hefnawy, Low cost biosorbent (Lemna gibba L.) for the removal of phenol from aqueous media, Journal of Mediterranean Ecology 14(2016), 55-62.

[92] E.S. Upatham, B. Boonyapookana, M. Kruatrachue, P. Pokethitiyook, K. Parkpoomkamol, Biosorption of cadmium and chromium in duckweed Wolffia globosa, International Journal of Phytoremediation 4(2002) 2, 73-86. https://doi.org/10.1080/15226510208500 074

[93] K. Zhang, T. Chen, Sorption and removal of iodate from aqueous solution using dried duckweed (Landoltia punctata) powder, Journal of Radioanalytical and Nuclear Chemistry 316(2018) 2, 543-551. https://doi.org/10.1007/s10967-0185807-3

[94] X.Q. Nie, F.Q. Dong, N. Liu, D. Zhang, M.X. Liu, J. Yang, W.. Zhang, Biosorption and biomineralization of uranium(VI) from aqueous solutions by Landoltia punctata, Spectroscopy and Spectral Analysis 35(2015) 9, 26132619.

[95] S. Yang, W. Wu, X. Hou, F. Wu, J. Lu, K. Xiang, Sorption of thorium(IV) from aqueous solutions by melamine modified Lemna minor, Huanjing Kexue Xuebao/Acta Scientiae Circumstantiae 37(2017), 1413-1418. http://doi.org/10.13671/j.hjkxxb.2016.03 $\underline{06}$

[96] P.K. Padmavathiamma, L.Y. Li, Rhizosphere influence and seasonal impact on phytostabilization of metals - 
a field study, Water, Air and Soil Pollution 223(2012) 1, 107-124. https://doi.org/10.1007/s11270-011$\underline{0843-4}$

[97] C. Stephenson, C.R. Black, One step forward, two steps back: the evolution of phytoremediation into commercial technologies, Bioscience Horizons 7(2014), 1-15. https://doi.org/10.1093/biohorizons/hzu0 $\underline{09}$

[98] E. Maestri, M. Marmiroli, G. Visioli, N. Marmiroli, Metal tolerance and hyperaccumulation: costs and trade-offs between traits and environment, Environmental and Experimental Botany 68(2010) 1, 1-13. https://doi.org/10.1016/j.envexpbot.2009 .10 .011

[99] H.I. Tak, F. Ahmad, O.O. Babalola, Advances in the application of plant growth-promoting Rhizobacteria in phytoremediation of heavy metals, in: Reviews of Environmental Contamination and Toxicology, ed. D.M. Whitacre, Volume 223, 2013, Springer, New York, 33-52. https://doi.org/10.1007/978-1-46145577-6_2

[100] A. Ullah, S. Heng, M.F.H. Munis, S. Fahad, X. Yang, Phytoremediation of heavy metals assisted by plant growth promoting (PGP) bacteria: a review, Environmental and Experimental Botany 117(2015), 28-40. https://doi.org/10.1016/j.envexpbot.201 5.05 .001

[101] B. Nowack, R. Schulin, B.H. Robinson, Critical assessment of chelantenhanced metal phytoextraction, Environmental Science and Technology 40(2006) 17, 5225-5232. https://doi.org/10.1021/es0604919

[102] A. Johnson, N. Singhal, Increased uptake of chelated copper ions by Lolium perenne attributed to amplified membrane and endodermal damage, International Journal of Molecular Sciences 16(2015) 10, 25264-25284. https://doi.org/10.3390/ijms161025264

[103] B.H. Robinson, G. Banuelos, H.M. Conesa, M.W.H. Evangelon, R.
Schulin, The phytomanagement of trace elements in soil, Critical Reviews in Plant Sciences 28(2009) 4, 240-266. https://doi.org/10.1080/0735268090303 5424

[104] B.R. Singh, S.K. Gupta, H. Azaizeh, S. Shilev, D. Sudre, W.Y. Song, E. Martinoi, M. Mench, Safety of food crops on land contaminated with trace elements, Journal of the Science of Food and Agriculture 91(2011) 8, 1349-1366.

https://doi.org/10.1002/jsfa.4355

[105] M. Mench, N. Lepp, V. Bert, J.P. Schwitzguébel, S.W. Gawronski, P. Schrőder, J. Vangronsveld, Successes and limitations of phytotechnologies at field scale: outcomes, assessment and outlook from COST Action 859, Journal of Soils and Sediments 10(2010) 6, 1039-1070. https://doi.org/10.1007/s11368-0100190-X

[106] T. Vamerali, M. Bandiera, G. Mosca, Field crops for phytoremediation of metal-contaminated land - A review, Environmental Chemistry Letters 8(2010) 1, 1-17. https://doi.org/10.1007/s10311-009$\underline{0268-0}$

[107] A. Pelfrêne, A. Kleckerová, B. Pourrut, F. Nsanganwimana, F. Douay, C. Waterlot, Effect of Miscanthus cultivation on metal fractionation and human bioaccessibility in metalcontaminated soils: comparison between greenhouse and field experiments, Environmental Science and Pollution Research 22(2015) 4, 3043-3054.

https://doi.org/10.1007/s11356-0143585-1

[108] J. Hua, C. Zhang, Y. Yin, R. Chen, X. Wang, Phytoremediation potential of three aquatic macrophytes in manganese-contaminated water, Water and Environment Journal 26(2012) 3, 335-342.

https://doi.org/10.1111/j.17476593.2011.00293.x

[109] C.J. da-Silva, R.A. Canatto, A.A. Cardoso, C. Ribeiro, J.A. Oliveira, 
Arsenic-hyperaccumulation and antioxidant system in the aquatic macrophyte Spirodela intermedia W. Koch (Lemnaceae), Theoretical and Experimental Plant Physiology 29(2017) 4, 203-213. https://doi.org/10.1007/s40626-0170096-8

[110] M.A. Maine, N.L. Suñé, S.C. Lagger, Chromium bioaccumulation: Comparison of the capacity of two floating aquatic macrophytes, Water Research 38(2004) 6, 1494-1501. https://doi.org/10.1016/j.watres.2003.1 2.025

[111] M.A. Jayasri, K. Suthindhiran, Effect of zinc and lead on the physiological and biochemical properties of aquatic plant Lemna minor: Its potential role in phytoremediation, Applied Water Sciences 7(2017) 3, 1247-1253. https://doi.org/10.1007/s13201-0150376-X

[112] Y. Xue, J. Wang, J. Huang, F. Li, M. Wang, The response of duckweed (Lemna minor L.) roots to $\mathrm{Cd}$ and its chemical forms, Journal of Chemistry 2018(2018), 1-9. https://doi.org/10.1155/2018/7274020

[113] P. Skillicorn, W. Spira, W. Journey, Duckweed Aquaculture: A new aquatic farming system for developing countries, The World Bank, Washington DC, 1993.

[114] Y. Zhao, Y. Fang, Y. Jin, J. Huang, S. Bao, T. Fu, Z. He, F. Wang, H. Zhao, Potential of duckweed in the conversion of wastewater nutrients to valuable biomass: A pilot-scale comparison with water hyacinth, Bioresource Technology 163(2014), 82-91.

https://doi.org/10.1016/j.biortech.2014. 04.018

[115] P. Fourounjian, T. Fakhoorian, X.H. Cao, Importance of duckweeds in basic research and their industrial applications, in: The Duckweed Genomes, ed. X.H. Cao, P. Fourounjian, W. Wang, Springer Nature, Switzerland, 2020, 1-17. https://doi.org/10.1007/978-3-03011045-1_1

[116] J. Goopy, P. Murray, A review on the role of duckweed in nutrient reclamation and as a source of animal feed, Asian-Australian Journal of Animal Sciences 16(2003) 2, 297-305. https://doi.org/10.5713/ajas.2003.297

[117] D.L. Childers, J. Corman, M. Edwards, J.J. Elser, Sustainability challenges of phosphorus and food: Solutions from closing the human phosphorus cycle, Bioscience 61(2011) 2, 117-124. https://doi.org/10.1525/bio.2011.61.2.6

[118] J. Yuan, K. Xu, Effects of simulated microgravity on the performance of the duckweeds Lemna aequinoctialis and Wolffia globosa, Aquatic Botany 137(2017), 65-71. https://doi.org/10.1016/j.aquabot.2016. $\underline{11.010}$

[119] P. Balaji, P.K. Satheeshkumar, K. Venkataraman, M.A. Vijayalakshmi, Expression of anti-tumor necrosis factor alpha (TNFalpha) single-chain variable fragment $(\mathrm{scFv})$ in Spirodela punctata plants transformed with Agrobacterium tumefaciens, Biotechnology and Applied Biochemistry 63(2016) 3, 354-361. https://doi.org/10.1002/bab.1373

[120] J.R. Gasdaska, D. Spencer, L. Dickey, Advantages of therapeutic protein production in aquatic plant Lemna, Bioprocessing Journal 2(2003) 2, 4956.

https://doi.org/10.12665/J22.GASDAS $\underline{\mathrm{KA}}$

[121] N. Wang, G. Xu, Y. Fang, T. Yang, H. Zhao, G. Li, New flavanol and cycloartane glucosides from Landoltia punctata, Molecules 19(2014) 5, 66236634.

https://doi.org/10.3390/molecules 1905 6623

[122] M. Shahid, B. Pourrut, C. Dumat, M. Nadeem, M. Aslam, E. Pinelli, Heavymetal-induced reactive oxygen species: Phytotoxicity and physicochemical changes in plants, Reviews of Environmental Contamination and Toxicology 232(2014), 1-44. 
https://doi.org/10.1007/978-3-319-

06746-9_1

[123] V. Dushenkov, P.B.A.N. Kumar, H. Motto, I. Raskin, Rhizofiltration: The use of plants to remove heavy metals from aqueous streams, Environmental Science and Technology 29(1995) 5, 1239-1245.

https://doi.org/10.1021/es00005a015

[124] http://www.life-lemna.eu/theproject/description/, Accessed: October 19, 2020. 